\title{
The Isolation of Antioxidant Enzymes from Mature Tomato (cv. Micro-Tom) Plants
}

\author{
Priscila L. Gratão, Carolina C. Monteiro, Lázaro E.P. Peres, \\ and Ricardo Antunes Azevedo ${ }^{1}$ \\ Escola Superior de Agricultura Luiz de Queiroz, Universidade de São Paulo, \\ Piracicaba, SP 13418-900, Brazil
}

Additional index words. antioxidant enzymes, catalase, 'Micro-Tom', superoxide dismutase

\begin{abstract}
The activity of catalase (CAT), guaiacol peroxidase (GPOX), ascorbate peroxidase (APX), glutathione reductase (GR), and the isoenzymes of superoxide dismutase (SOD) were determined in the organs of tomato (Lycopersicon esculentum) cultivar Micro-Tom after 104 days of development. The total activities of CAT, GPOX, and GR were higher in the stem than in others tissues, whereas the stem exhibited the lowest APX activity. Activity staining analysis following gel electrophoresis revealed the existence of four SOD isoenzymes in leaves, three in fruits, but only two in the roots and stems. This characterization is essential for an investigation into the effect of abiotic and biotic stresses on the oxidative stress responses by this plant model system.
\end{abstract}

Several model systems have been used to understand biological phenomena, providing insights into the how plants function (Lea and Azevedo, 2006, 2007). For this purpose, tomato can be considered as an excellent material as it contains a wide variety of secondary metabolites that can facilitate biochemical and physiological analyses as well as being an important crop species (Gent, 2007; Lee et al., 2007; Smith et al., 2007). In addition to being an alternative model plant to Arabidopsis thaliana (Lima et al., 2004), tomato can also be a model crop for studies with flesh berry fruits (Sun et al., 2006). The miniature cultivar of tomato (Micro-Tom) has been proposed to be used as a genetic model based on the small size, growth at a high density, and production of viable fruits and seeds in containers with 50 to $100 \mathrm{~mL}$ of substrate, all within a reduced life cycle ranging between 70 and $100 \mathrm{~d}$ (Meissner et al., 1997). Moreover, the Micro-Tom cultivar can be grown in laboratories with the same minimum structure used for $A$. thaliana. However, this cultivar is poorly characterized, particularly when antioxidant enzymes are concerned. Such basic information is essential and will help to improve our understanding about some of the basic physiological mechanisms related to the control of

\footnotetext{
Received for publication 24 Jan. 2008. Accepted for publication 5 Mar. 2008.

This work was funded by Fundação de Amparo à Pesquisa do Estado de São Paulo (FAPESP; Grant no. 04/08444-6).

R.A.A. and P.L.G. thank the Conselho Nacional de Desenvolvimento Científico e Tecnológico (CNPq-Brazil) for the fellowship and scholarship granted. We also thank Prof. Peter Lea for the critical reading of the manuscript.

${ }^{1}$ To whom reprint requests should be addressed; e-mail raazeved@esalq.usp.br
}

reactive oxygen species (ROS) normally produced in cells if oxidative stress conditions are to be studied. Given the vast complexity of antioxidative systems (Garcia et al., 2006; Wahid and Ghani, 2008), we have concentrated our attention on some of the key antioxidant enzymes such as catalase (CAT), guaiacol peroxidase (GPOX), ascorbate peroxidase (APX), glutathione reductase (GR), and superoxide dismutase (SOD).

The Micro-Tom cultivar was kindly provided by Dr. A. Levy (Weizmann Institute of Science, Rehovot, Israel). Seeds were sown in boxes containing a mixture of $1: 1$ (by volume) commercial pot mix (Plantmax HT Eucatex, São Paulo, Brazil) and vermiculite supplemented with $1 \mathrm{~g}$ of $10 \mathrm{~N}-10 \mathrm{P}-10 \mathrm{~K}$ and $4 \mathrm{~g} \mathrm{lime} / \mathrm{L}$ of mixture. Once the first true leaves appeared, seedlings were transplanted to $150-\mathrm{mL}$ pots (two per pot). After $104 \mathrm{~d}$ of development, root, stem, leaf, and fruit (at red ripe stage) samples were collected and stored at $-80{ }^{\circ} \mathrm{C}$ for further analyses. The samples were homogenized $(2: 1$ buffer volume: fresh weight) in a mortar with a pestle with $100 \mathrm{~mm}$ potassium phosphate buffer ( $\mathrm{pH} 7.5)$ containing $1 \mathrm{~mm}$ ethylenediaminetetraacetic acid, $3 \mathrm{~mm}$ DL-dithiothreitol, and 5\% (w/v) insoluble polyvinylpolypyrrolidone (Azevedo et al., 1998). The homogenate was centrifuged at $10,000 \mathrm{~g}$ for $30 \mathrm{~min}$ and the supernatant was kept stored in separate aliquots at $-80^{\circ} \mathrm{C}$. CAT, GPOX, APX, and GR activities were determined as described by Gomes-Junior et al. (2006b) and expressed in $\mu \mathrm{mol} \cdot \mathrm{min}^{-1} \cdot \mathrm{mg}^{-1}$ protein for CAT, APX, and GR and units (U), which can be defined as one enzyme activity unit corresponding to an increase of 0.001 in absorbance per min, for GPOX. SOD activity determinations after nondenaturing polyacrylamide gel electrophoresis (PAGE) were carried out as described by Gomes-Junior et al. (2007). Electrophoresis buffers and gels were pre- pared as described by Vitória et al. (2001) except that sodium dodecyl sulphate was excluded. The experimental design was randomized with three replicates for each pot and the results were expressed as the mean and SEM).

Although toxic, ROS are normally produced and metabolized by the cell system. However, under stressful conditions, some compounds are produced in excess and must be rapidly detoxified by a series of enzymatic and nonenzymatic mechanisms, which prevents the formation of destructive radicals, thus protecting against uncontrolled oxidation (Gratão et al., 2005; Pauly et al., 2006; Pitzschke et al., 2006). Understanding such defense responses has gained importance recently, resulting in a dramatic increase in the number of reports related to the effects of stress factors on a large variety of plant species. Tomato is an important plant model and may be used to better understand these defense mechanisms.

After $104 \mathrm{~d}$ of development, 'Micro-Tom' plants exhibited some distinct activity patterns for the enzymes tested. Of all the tissues analyzed, the stem was shown to contain the highest total CAT and GPOX activities (Fig. 1A-B). CAT can represent the major constituent of the peroxisomal matrix in photosynthetic tissues (Reumann and Weber, 2006), whereas GPOX can metabolize $\mathrm{H}_{2} \mathrm{O}_{2}$ at rates that are low compared with the high rates of $\mathrm{H}_{2} \mathrm{O}_{2}$ generation in plants (Noctor et al., 2002).

The trend of APX activity was the opposite of that observed for the other two peroxidases analyzed, exhibiting the lowest activity in the stem and the highest in the fruit tissue (Fig. 1C). APX is involved in the conversion of $\mathrm{H}_{2} \mathrm{O}_{2}$ to $\mathrm{H}_{2} \mathrm{O}$ using ascorbate as the specific electron donor, thus protecting chloroplasts and other cell constituents from damage by $\mathrm{H}_{2} \mathrm{O}_{2}$ and $\mathrm{OH}$ (Teixeira et al., 2006). APX is localized in the stroma and thylakoid of higher plant chloroplasts and can be inactivated by $\mathrm{H}_{2} \mathrm{O}_{2}$ if the second substrate ascorbate is depleted (Kitajima et al., 2006). During senescence, the expression of the individual APX genes is differentially regulated, indicating a precise control of $\mathrm{H}_{2} \mathrm{O}_{2}$ concentrations in different cell compartments during plant development (Panchuk et al., 2005).

The highest GR activity was observed in the stem among the tissues tested but was shown to be considerably reduced in the leaf tissue (Fig. 1D). GR can be involved in defense against oxidative stress, whereas reduced GSH plays an important role in the breakdown of $\mathrm{H}_{2} \mathrm{O}_{2}$ because it is able to reduce this compound either nonenzymatically or serving as a substrate for peroxidasecatalyzed reactions (Noctor et al., 2002).

In $A$. thaliana, two genes encoding GR have been identified, $g r l$ and $g r 2$, encoding cytosolic and plastidic GR isoenzymes, respectively (Xiang and Oliver, 1998), but the number of isoenzymes can be higher as observed in coffee cell suspension cultures (Gomes-Junior et al., 2006a, 2007). 
Up to five distinct SOD isoenzymes were identified following PAGE among the four tomato organs tested (Fig. 2). SOD I was clearly present in all the samples tested, whereas SOD II and SOD IV were only detected in the leaves. SOD III could be detected in the root, stem, and fruit, but not in the leaves, whereas SOD V appeared to be Although a distinct SOD isoenzyme pattern was detected in all samples tested, the total SOD activity determined by densitometric analysis (data not shown) was clearly much higher in the stem and fruit samples with SOD I accounting for the majority of SOD activity in all organs (Fig. 2). SOD is responsible for the dismutation of $\mathrm{O}_{2}{ }^{-}$into $\mathrm{H}_{2} \mathrm{O}_{2}$, influencing the concentration of $\mathrm{O}_{2}{ }^{-}$and only present in the leaves and fruits.

$\mathrm{H}_{2} \mathrm{O}_{2}$ in the cell. Three distinct types of SOD isoenzymes have been detected in plants, which are classified according to their metal cofactor $\mathrm{Fe}, \mathrm{Mn}$, and $\mathrm{Cu} / \mathrm{Zn}$ (Gratão et al., 2005). Fe-SOD has been shown to be associated with the chloroplasts; Mn-SODs are located in the mitochondria and peroxisomes, while the $\mathrm{Cu} / \mathrm{Zn}$-SODs are located in the cytosol, chloroplasts, and peroxisomes (Gratão et al., 2005). According to the results obtained with the 104-d-old 'Micro-Tom' plant, it is proposed that CAT and GPOX play important roles in metabolizing $\mathrm{H}_{2} \mathrm{O}_{2}$ in the stems, whereas APX would appear to be more important in such a role in the fruits. Overall, it is important to note that such activity trends are specific for this late stage of development in which the fruit tissue
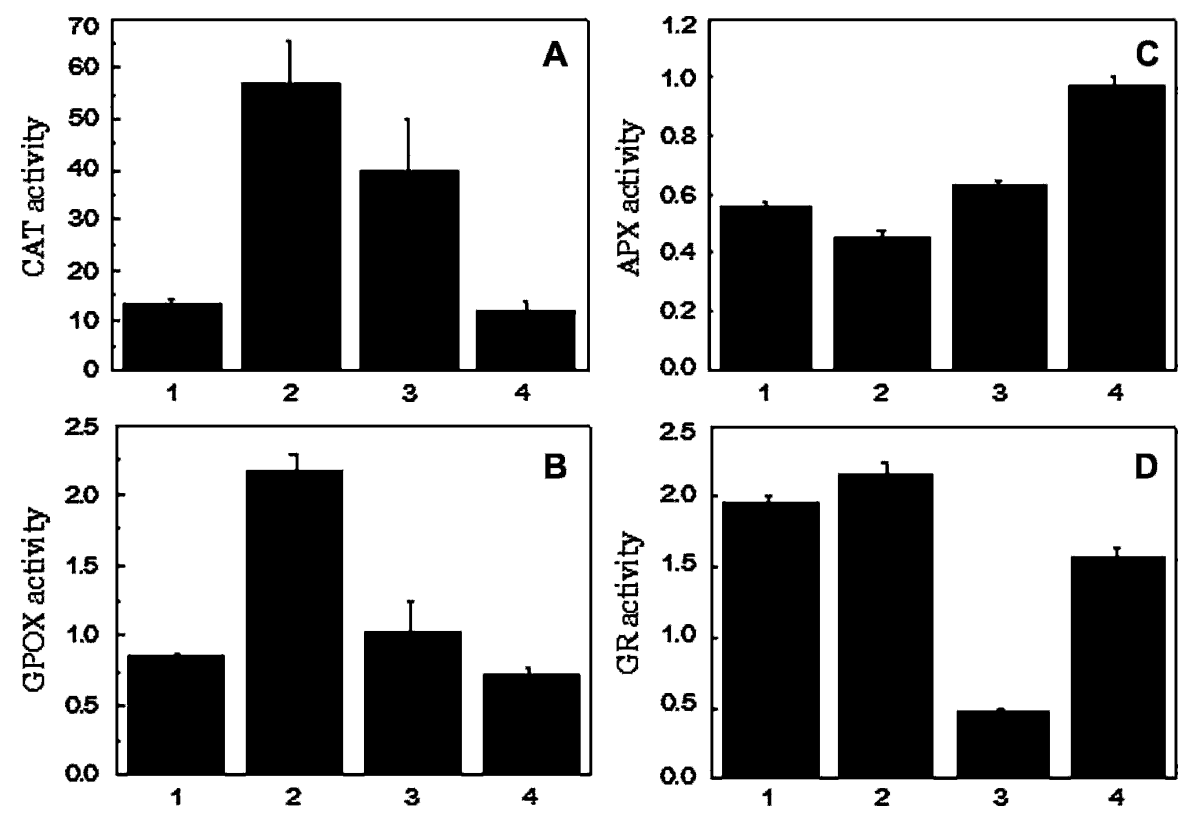

Fig. 1. Specific activity of (A) catalase $\left(\mu \mathrm{mol} \cdot \mathrm{min}^{-1} \cdot \mathrm{mg}^{-1}\right.$ protein $),(\mathbf{B})$ guaiacol peroxidase $(\mathrm{U}),(\mathbf{C})$ ascorbate peroxidase $\left(\mu \mathrm{mol} \cdot \mathrm{min}^{-1} \cdot \mathrm{mg}^{-1}\right.$ protein), and (D) glutathione reductase $\left(\mu \mathrm{mol} \cdot \mathrm{min}^{-1} \cdot \mathrm{mg}^{-1}\right.$ protein) grown for a 104-d period. (1) Root, (2) stem, (3) leaf, and (4) fruit. Values are the means of three replicates \pm SEM.

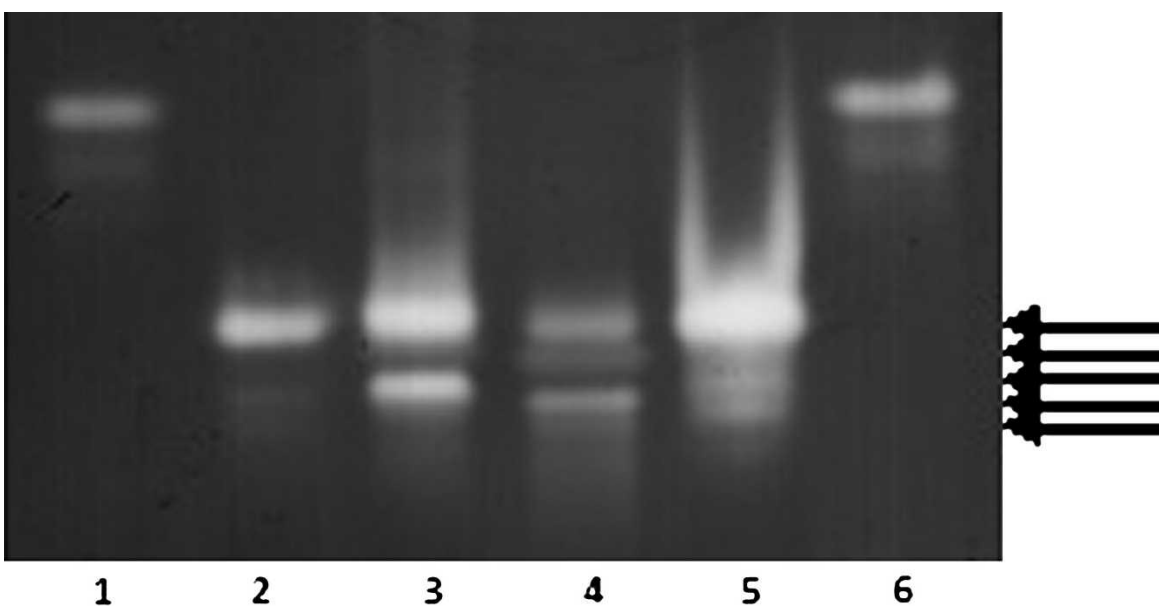

Fig. 2. Superoxide dismutase (SOD) activity staining after native polyacrylamide gel electrophoresis of extracts of 'Micro-Tom'. Lanes 1 and 6, bovine SOD; lane 2, root; lane 3, stem; lane 4, leaf; and lane 5, fruit. Arrows from top to bottom indicate SOD isoenzyme bands I, II, III, IV, and V. could also be analyzed. Nevertheless, the information indicates that distinct antioxidant enzymes make a different contribution to the oxidative state of the cell, which may also be expected for other stages of development. In conclusion, differential responses by CAT, GPOX, APX, GR, and SOD may be correlated to specific cell physiological phenomena as a result of their organ location. Using this information for the model crop 'Micro-Tom' tomato, stressful situations may be better understood. For instance, it is important when setting up an experiment to analyze heavy metal contamination, in which the metal can be translocated and accumulated in the fruit tissue, which is obviously undesirable and dangerous if the fruit is to be consumed by humans. An ongoing major project is being conducted in our laboratory in which the 'Micro-Tom' tomato is being subjected to growth up to maturity and fruit production in the presence of several heavy metals.

\section{Literature Cited}

Azevedo, R.A., R.M. Alas, R.J. Smith, and P.J. Lea. 1998. Response of antioxidant enzymes to transfer from elevated carbon dioxide to air and ozone fumigation, in the leaves and roots of wild-type and a catalase-deficient mutant of barley. Physiol. Plant. 104:280-292.

Garcia, J.S., P.L. Gratão, R.A. Azevedo, and M.A.Z. Arruda. 2006. Metal contamination effects on sunflower (Helianthus annuиs L.) growth and protein expression in leaves during development. J. Agr. Food Chem. 54:86238630.

Gent, M.P.N. 2007. Effect of degree and duration of shade on quality of greenhouse tomato. HortScience 42:514-520.

Gomes-Junior, R.A., P.L. Gratão, S.A. Gaziola, P. Mazzafera, P.J. Lea, and R.A. Azevedo. 2007. Selenium-induced oxidative stress in coffee cell suspension cultures. Funct. Plant Biol. 34:449-456.

Gomes-Junior, R.A., C.A. Moldes, F.S. Delite, P.L Gratão, P. Mazzafera, P.J. Lea, and R.A. Azevedo. 2006a. Nickel elicits a fast antioxidant response in Coffea arabica cells. Plant Physiol. Biochem. 44:420-429.

Gomes-Junior, R.A., C.A. Moldes, F.S. Delite, G.B. Pompeu, P.L. Gratão, P. Mazzafera, P.J. Lea, and R.A. Azevedo. 2006b. Antioxidant metabolism of coffee cell suspension cultures in response to cadmium. Chemosphere 65: 1330-1337.

Gratão, P.L., A. Polle, P.J. Lea, and R.A. Azevedo 2005. Making the life of heavy metal-stressed plants a little easier. Funct. Plant Biol. 32:481494

Kitajima, S., K. Tomizawa, S. Shigeoka, and A. Yokota. 2006. An inserted loop region of stromal ascorbate peroxidase is involved in its hydrogen peroxide-mediated inactivation. Febs J. 73:2704-2710.

Lea, P.J. and R.A. Azevedo. 2006. Nitrogen use efficiency. 1. Uptake of nitrogen from the soil. Ann. Appl. Biol. 149:243-247.

Lea, P.J. and R.A. Azevedo. 2007. Nitrogen use efficiency. 2. Amino acid metabolism. Ann. Appl. Biol. 151:269-275.

Lee, E., S.A. Sargent, and D.J. Huber. 2007. Physiological changes in Roma-type tomato induced by mechanical stress at several ripeness stages. HortScience 42:1237-1242. 
Lima, J.E., R.F. Carvalho, A. Tulmann Neto, A. Figueira, and L.E.P. Peres. 2004. Micro-Msk: A tomato genotype with miniature size, short life cycle and improved in vitro shoot regeneration. Plant Sci. 167:753-757.

Meissner, R., Y. Jacobson, S. Melamed, S. Levyatuv, G. Shalev, A. Ashri, Y. Elkind, and A. Levy. 1997. A new model system for tomato genetics. Plant J. 12:1465-1472.

Noctor, G., L. Gomez, H. Vanacker, and C.H. Foyer. 2002. Interactions between biosynthesis, compartmentation and transport in the control of glutathione homeostasis and signalling. J. Expt. Bot. 53:1283-1304.

Panchuk, I.I., U. Zentgraf, and R.A. Volkov. 2005. Expression of the Apx gene family during leaf senescence of Arabidopsis thaliana. Planta 222:926-932.

Pauly, N., C. Pucciariello, K. Mandon, G. Innocenti, A. Jamet, E. Baudouin, D. Herouart, P.
Frendo, and A. Puppo. 2006. Reactive oxygen and nitrogen species and glutathione: Key players in the legume-Rhizobium symbiosis. J. Expt. Bot. 57:1769-1776.

Pitzschke, A., C. Fornazi, and H. Hirt. 2006. Reactive oxygen species signalling in plants. Antioxid. Redox Sign. 8:17571764.

Reumann, S. and A.P.M. Weber. 2006. Plant peroxisomes respire in the light: Some gaps of the photorespiratory $\mathrm{C}-2$ cycle have become filled-Others remain. BBA-Mol. Cell Res. 1763:1496-1510.

Smith, S.M., J.W. Scott, J.A. Bartz, and S.A. Sargent. 2007. Effect of time after harvest on stem scar water absorption in tomato. HortScience 42:1227-1230.

Sun, H.J., S. Uchii, S. Watanabe, and H. Ezura. 2006. A high efficient transformation protocol for Micro-Tom, a model cultivar for tomato functional genomics. Plant Cell Physiol. 47:426-431.

Teixeira, F.K., L. Menezes-Benavente, V.C. Galvão, R. Margis, and M. Margis-Pinheiro. 2006. Rice ascorbate peroxidase gene family encodes functionally diverse isoforms localized in different subcellular compartments. Planta 224: 300-314.

Vitória, A.P., P.J. Lea, and R.A. Azevedo. 2001. Antioxidant enzymes responses to cadmium in radish tissues. Phytochemistry 57:701-710.

Xiang, C. and D.J. Oliver. 1998. Glutathione metabolic genes coordinately respond to heavy metals and jasmonic acid in Arabidopsis. Plant Cell 10:1539-1550.

Wahid, A. and A. Ghani. 2008. Varietal differences in mung bean (Vigna radiata) for growth, yield, toxicity symptoms and cadmium accumulation. Ann. Appl. Biol. 152:59 69. 